\title{
Korupsi dan mentalitas: kendala kultural dalam pemberantasan korupsi di Indonesia
}

\author{
Corruption and mentality: \\ cultural obstacles in combating corruption in Indonesia
}

\author{
Listiyono Santoso, Dewi Meyriswati, Ilham Nur Alfian \\ Jurusan Sastra Indonesia, FIB, Universitas Airlangga \\ Jalan Airlangga 4-6 Surabaya 60286, Indonesia \\ E-mail: alisy00@yahoo.com
}

\begin{abstract}
Corruption is a complex act of crime. Its complexity does not only deal with legal issue but also social, political, and cultural issues. Law approach is more widely used in the eradication of corruption because corruption is a matter of law. However, seeing a corruption as a matter of law issue is the way to simplify the problem. The complexity of corruption makes this issue is feasibly approached through a variety of perspectives, one of those is cultural approach. The aim of this research is to reveal the cultural obstacles in eradicating corruption in Indonesia as well as to describe cultural conditions which led to a massive corruption. Formal juridical approach in eradicating corruption is considered to be done in a large number although they did not show maximal results. Such massive corruption in Indonesia seems to draw a conclusion that corruption has become a culture of the citizens of our nation. It means that there is a variety of cultural symptoms which encourage the act of corruption performed easily in every institution. There is a low mentality culture in the heart of the corruptor to carry out the action. That is why; we need a strategy in order to eradicate the culture of corruption in Indonesia.
\end{abstract}

Keywords: cultural approach, corruption, mentality and cultural strategy

\begin{abstract}
Abstrak
Korupsi merupakan fenomena kejahatan yang bersifat kompleks. Tidak hanya berkaitan dengan persoalan hukum, melainkan juga persoalan sosial politik dan kebudayaan. Pendekatan hukum lebih banyak digunakan dalam pemberantasan korupsi, karena korupsi memang merupakan persoalan hukum. Namun demikian, melihat korupsi hanya sebagai persoalan hukum adalah menyederhanakan persoalan. Kompleksitas korupsi menjadikan persoalan ini layak didekati melalui berbagai perspektif, salah satunya adalah pendekatan kebudayaan. Penelitian ini bertujuan untuk mengungkapkan berbagai kendala kultural pemberantasan korupsi di Indonesia, sekaligus mendeskripsikan kondisi-kondisi kultural yang mendorong terjadinya korupsi yang begitu masif. Pendekatan yuridis formal dalam melakukan pemberantasan korupsi dinilai sudah banyak dilakukan, meskipun belum menunjukkan hasil yang maksimal. Begitu masifnya korupsi terjadi di Indonesia seolah memberikan simpulan bahwa korupsi telah menjadi kebudayaan warga bangsa kita. Artinya, terdapat berbagai gejala-gejala kebudayaan yang mendorong korupsi mudah dilakukan di setiap lembaga. Ada mentalitas kebudayaan yang rendah dalam ruang batin pelaku korupsi untuk menjalankan aksinya. Itulah sebabnya, diperlukan suatu strategi kebudayaan dalam rangka pemberantasan korupsi di Indonesia.
\end{abstract}

Kata-kata kunci : hambatan kultural, korupsi, mentalitas, dan strategi kebudayaan

\section{Pendahuluan}

Korupsi secara sederhana dipahami sebagai upaya menggunakan kemampuan campur tangan karena posisinya untuk menyalahgunakan informasi, keputusan, pengaruh, uang atau kekayaan untuk kepentingan keuntungan dirinya (Haryatmoko 2011:123). Korupsi terjadi karena penyalahgunaan kewenangan kekuasan tidak untuk kepentingan bersama, melainkan kepentingan diri sendiri atau kelompoknya. 
Penyalahgunaan kewenangan seringkali terjadi bukan saja karena sistem pengawasan tidak berjalan, melainkan juga karena problema mentalitas kebudayaan yang berhimpun dalam struktur birokrasi yang berjalan dalam pemerintahan. Mentalitas tersebut tidak lain adalah kultur feodalistik dalam wajah pengelolaan birokrasi pemerintahan. Meskipun sistem birokrasi dikelola secara rasional modern, tetapi karena kultur yang berjalan masih tradisional berdasarkan warisan lalu, maka sistem feodalisme menjadi tantangan yang tidak mudah untuk diurai dalam birokrasi modern kita. Dalam wajah birokrasi yang demikian maka langgam birokrasi seringkali seperti struktur dalam keluarga dengan sistem kekerabatan yang kuat. Tidak berlebihan jika kemudian sistem kekerabatan dalam langgam birokrasi di negeri ini berpeluang terjadinya fenomena birokrasi kolutif, koruptif, dan nepotif.

Upaya untuk meminimalisir terjadinya korupsi di Indonesia sudah banyak dilakukan. Tidak saja melalui aspek yuridis formal, melainkan juga melalui berbagai kampanye anti korupsi lewat posterposter dan famlet-famlet. Bahkan terbaru mulai diselenggarakannya mata pelajaran Pendidikan Anti Korupsi di sekolah-sekolah formal. Berbagai kegiatan ini menunjukkan bukti bahwa korupsi merupakan musuh bersama yang dapat mengancam masa depan bangsa Indonesia ini. Sebagai musuh, maka wajar jika korupsi harus selalu diperangi dan diberantas hingga ke akar-akarnya.

Namun demikian, pendekatan di atas belum menunjukkan hasil yang memuaskan. Buktinya berbagai tindakan korupsi tetap banyak terjadi. Hampir setiap hari kita menyaksikan di telivisi atau membaca di media massa korupsi masih tetap terjadi, dimanapun dan kapanpun. Setiap ada koruptor ditanggkap, meski itu dianggap sebagai prestasi penegaka hukum, tapi dari sisi kebudayaan, hal ini merupakan sisi tragis mentalitas korup yang tidak terbendung. Dalam konteks demikian, maka korupsi merupakan tragedi moralitas kebudayaan yang sedang bermasalah. Ada suatu kondisi dalam alam kebudayaan kita yang mendorong orang melakukan tindakan korupsi. Begitu pula, ada kendalakendala kultural mengapa korupsi tetap begitu masif terjadi, sehingga pemberantasan terhadap korupsi selalu tidak pernah tuntas.

Realitas demikian menunjukkan bahwa korupsi bukanlah sekedar persoalan hukum, melainkan juga persoalan kebudayan. Penelitian ini -dalam banyak hal- merupakan library research yang berusaha mengungkapkan hambatan kebudayaan dalam pemberantasan korupsi di Indonesia, meskipun dengan tidak mengabaikan realitas empirik berupa persepsi dan kontsruksi publik terkait dengan problema korupsi di Indonesia yang dilakukan dengan pendekatan fenomenologi. Pendekatan ini diperlukan dalam rangka mengungkapkan keadaan yang sesungguhnya dari masyarakat terkait dengan fenomena korupsi yang selama ini dipahami dan dipersepsikan oleh publik.

\section{Korupsi sebagai problem kultural: konstruksi teoritik}

Alam kebudayaan masyarakat kita sesungguhnya adalah masyarakat agraris dengan komunalitasnya. Masyarakat yang demikian selalu menunjukkan keinginan untuk hidup bersama secara damai dan harmonis. Karenanya, mereka cenderung menghindari konflik agar harmonisasi dalam masyarakat terjadi. Setiap kegiatan yang melanggar harmonisasi, akan dianggap sebagai anomali (menyimpang) dan layak untuk dikenai sanksi sosial. Dalam konstruksi tersebut, masyarakat cenderung 'diam' ketika ada hal-hal yang mungkin tidak disepakatinya. Alasan utama mengedepankan harmonisasi sosial menjadi pilihan untuk membiarkan berbagai kemungkinan pelanggaran hukum seperti korupsi. Misalnya, ketika ada kolega atau tetangga yang melakukan aktivitas yang mengarah pada tindakan memperkaya diri, cenderung dibiarkan, karena khawatir terjadi konflik di dalamnya.

Masyarakat agraris meminjam terminologi Magnis Suseno (1999:43) cenderung memiliki sikap untuk memperkatakan hal-hal yang tidak enak secara tidak langsung. Orang Jawa mampu menutupi kekecewaannya melalui kebiasaan berpura-pura (ethok-ethok). Kemampuan ini dianggap sebagai keutamaan hidup, sebagai seni yang tinggi dan bernilai positif. Terhadap yang tidak disukainya, orang Jawa akan menyampaikan melalui sikap tidak langsung atau menyembunyikan perasaan kekecewaan tersebut, kecuali pada keluarga inti. Belum lagi, berbagai kendala kebudayaan lainnya yang turut serta menghambat pemberantasan korupsi, tetapi justru menyuburkan peluang korupsi selalu terjadi. 
Pendekatan kebudayaan dalam penanganan korupsi tidak saja bermanfaat untuk mencegah terjadinya korupsi, tapi dapat digunakan sebagai penciptaan strategi kebudayaan dalam pencegahan korupsi secara komprehensif. Pendekatan kebudayaan akan menyentuh berbagai kondisi mentalitas, moralitas dan alam pikiran yang melingkupi berbagai peristiwa korupsi begitu mudah terjadi di Indonesia, serta begitu sulitnya tindakan korupsi itu dicegah dan diberantas.

Selama ini masyarakat cenderung memahami bahwa korupsi itu merupakan problema yuridis semata, dan hanya bisa didekati dengan pendekatan hukum. Korupsi itu sesungguhnya terkait juga dengan suatu perilaku yang didorong oleh mentalitas kebudayaan dan alam pikiran yang menjadikan 'harta' dan 'tahta' sebagai hal yang utama, yakni sebagai alat untuk memperkaya diri bukan untuk pengabdian kepada kepentingan publik. Korupsi terjadi karena pelaku menganggap bahwa dibalik kekuasaan yang dimilikinya, termasuk kekuasaan pengelolaan keuangan, adalah suatu berkah bagi kehidupannya. Kekuasaan tidak lagi menjadi amanah yang suatu saat dipertanggungjawabkan kepada Tuhan dan publik. Itulah sebabnya, orientasi kekuasaan yang demikian lebih cenderung menitikberatkan pada pemuasaan hasrat kepemilikan 'harta' daripada hasrat menyalurkan manfaat bagi publik yang lebih luas. Melalui penelitian ini, berbagai hasrat (desire) yang berpotensi melahirkan perilaku korupsi tersebut dicoba untuk diungkapkan, sehingga deksripsi mendalam terhadap perilaku korup para koruptor dapat diungkapkan secara komprehensif. Dalam jangka panjang, disusun sebuah model strategi kebudayaan dalam rangka pemberantasan korupsi secara berkelanjutan.

Pendekatan kebudayaan merupakan perihal penting dalam setiap upaya membangun peradaban bangsa yang lebih baik, termasuk di dalamnya adalah soal pemberantasan dan pencegahan korupsi. Bersepakat dengan JWM Bakker (1984:11), dalam setiap soal, kebudayaan menampakkan diri sebagai faktor yang tidak dapat dielakkan, yang mau tidak mau harus diperhatikan agar setiap usaha (merancang masa depan) tidak menjadi gagal. Dari dalam kebudayaan orang menggali motif dan perangsang untuk menjunjung perkembangan masyarakat. Dari dalamnya juga berasal kebiasaan yang menyebabkan rusaknya tatanan sosial, seperti anarkisme, korupsi dan kemacetan. Artinya, bisa saja terjadi berbagai program pembangunan (kebijakan) gagal justru karena hambatan kebudayaan yang kita miliki.

Mengapa nilai menjadi penting dalam membentuk kemajuan? Lawrence E. Harrison and Samuel P. Hutington (2000) dalam Culture Matter: How Values Shape Human Progress mengatakan bahwa nilai dalam setiap budaya memiliki andil yang menentukan keberhasilan perubahan yang hendak ditentukan. Hutington, dkk (2000:xv) mendefinisikan budaya sebagai istilah yang subjektif seperti nilai-nilai, sikap, kepercayaan, orientasi, dan praduga mendasar yang lazim di antara orang-orang dalam suatu masyarakat. Mereka memberi contoh dua Negara Ghana dan Korea Selatan yang pada tahun 1960-an awal menyebutkan betapa miripnya ekonomi keduanya. Mereka memiliki Produk Domestik Bruto per kapita (PDB) yang setara, porsi ekonomi mereka yang serupa di antara produk manufacturing dan jasa primer, serta berlimpahnya ekspor produk primer. Pada tahun yang sama keduanya menerima bantuan ekonomi dalam jumlah yang seimbang. 30 tahun kemudian, Korea Selatan menjadi raksasa industrim dengan ekonomi terbesar ke-14 di dunia, sementara Ghana tidak ada perubahan sama sekali, bahkan PDB-nya seperlimabelas dari Korea Selatan.

Bagaimana menjelaskan perbedaan yang luar biasa dalam perkembangan ini? Tahun 90-an, Hutington dkk. meneliti keduanya. Ditemukan fakta mengejutkan bahwa tidak diragukan lagi ternyata budaya memainkan peran besar dalam membentuk peradaban masing-masing. Masyarakat Korea Selatan menghargai hidup hemat, investasi, kerja keras, pendidikan, organisasi, dan disiplin, sebaliknya Ghana mempunyai nilai yang berbeda yang justru menghambat terjadinya kemajuan bagi negara tersebut. Dalam konteks ini, strategi kebudayaan bisa dilakukan melalui dua cara; (1) teknologisasi kebudayaan dan; (2) rekayasa kebudayaan. Teknologisasi kebudayaan merupakan strategi bagaimana memaksa orang agar sesuai dengan prinsip nilai yang hendak dicapai, sedangkan rekayasa kebudayaan adalah melalui cara mendorong orang agar berbuat sesuai dengan prinsip nilai yang ditetapkan. Yang pertama bersifat mewajibkan, sedangkan yang kedua bersifat penyadaran. Tidak 
menjadi persoalan, mana yang harus didahulukan, mana yang belakangan, namun mendorong orang berbuat positif bukankah lebih baik dari pada memaksa orang untuk berbuat positif.

Dengan demikian, dalam kondisi-kondisi tertentu memang dibutuhkan teknologisasi kebudayaan. Dalam masyarakat yang serba permisif dan tidak memiliki semangat untuk hidup dalam tertib sosial, dibutuhkan kelompok penekan yang memaksa dan mewajibkannya mengikuti aturan main yang disepakati Michel Foucault dalam Dicipline and Punish (1975) mengatakan bahwa melalui pemaksaan diri, sebuah kekuasaan dapat mengontrol orang yang dikuasainya agar kian mudah dikuasai. Sementara rekayasa kebudayaan diperlukan pada masyarakat dalam situasi normal, masyarakat yang sejak awal memiliki kesadaran tentang pentingnya aturan main itu. Masyarakat yang sudah terbiasa hidup dalam tertib sosial, bergerak berdasarkan komitmen bersama.

Penjelasan di atas cukup penting dalam rangka meletakkan korupsi dalam konteks kebudayaan. Artinya, diperlukan juga suatu kajian terhadap sistem nilai yang disadari atau tidak dapat berpotensi membuat korupsi selalu terjadi. Pemberantasan korupsi dalam pendekatan kebudayaan akhirnya memaksa kita menjalankan dua fungsi sekaligus, yakni memaksa orang untuk taat asas pengelolaan kekuasaan, dan mendorong orang untuk menjadi baik dan bijak dalam pengelolaan kekuasaan agar korupsi bisa dicegah, yakni mempersiapkan sumberdaya manusia sekarang demi kepentingan masa depan kebangsaan Indonesia.

\section{Korupsi dalam mentalitas feodalistik}

Praktik korupsi begitu masif terjadi di Indonesia. Tidak hanya terjadi pada lembaga-lembaga eksekutif, melainkan juga terjadi dalam lembaga legislatif dan yudikatif. Korupsi yang semula hanya terjadi pada kalangan birokrasi, sekarang ini lingkaran setan korupsi politik juga melibatkan partai politik, politisi, kroni bisnis, hingga aparat penegak hukum. Belum selesai kasus Irjen Polisi Joko Susilo yang begitu mencengangkan publik, kini publik kembali dikagetkan dengan kasus yang menjerat Akil Mochtar, ketua Mahkamah Konstitusi. Cukup mengagetkan, karena sebagai penegak hukum, bahkan figur penting dalam menjaga koridor konstitusi di negara Indonesia, Akil Mochtar justru sedang menghadapi kasus suap yang kian membuat redupnya wibawa hukum dan pemerintahan. Tanda korupsi yang melanda berbagai institusi penegak hukum memberikan sinyal kuat betapa mentalitas korup dimiliki oleh setiap orang yang memiliki kekuasaan di dalamnya. Kekuasaan dalam konteks ini adalah kekuasaan kewenangan dalam bidang apapun terkait dengan pelayanan publik.

Berbagai fakta korupsi tersebut sesungguhnya menjadi suatu bukti bahwa korupsi berpotensi dilakukan oleh siapa saja, bahwa yang seharusnya menjadi penjaga gawang bagi diberlakukannya birokrasi yang anti korupsi pun hingga para penegah hukum. Hal ini menunjukkan betapa korupsi tidak saja menjadi persoalan hukum, melainkan juga merupakan persoalan mentalitas kebudayaan. Artinya, orang yang sangat mengerti dan paham tentang hukum pun dapat terjerat kasus korupsi, apalagi yang lain. Jika demikian, korupsi bukanlah sekedar persoalan hukum dan hanya bisa didekati dari aspek hukum semata, melainkan juga aspek lain yang melingkupinya. Aspek hukum hanyalah melihat korupsi sebagai problem yuridis semata dengan melihat perilaku dari sudut pandang hukum. Bahwa korupsi merupakan kasus hukum memang tidak bisa dipungkiri, tapi semata melihat korupsi hanya dalam perspektif hukum semata jelas menyederhanakan persoalan. Dalam banyak hal, aspek hukum lebih banyak menyentuh pada aspek material atau fakta hukum terjadinya korupsi.

Perspektif hukum lebih melihat korupsi sebagai fakta hukum, sehingga ia hanya bisa didekati melalui bukti adanya fakta material pelanggaran hukum. Seringkali tidak tersentuh adalah bahwa latar sosial budaya mengapa korupsi begitu mudah terjadi serta bagaimana korupsi sulit dicegah sebagai sebuah perilaku. Perspektif kebudayaan mencoba meletakkan korupsi sebagai problem mentalitas yang memberikan peluang terjadinya korupsi sekaligus kecenderungan membiarkan korupsi selalu terjadi dalam lingkungan pekerjaan. Menurut Bambang Widjajanto (dalam Hartiningsih 2011:344) mengatakan bahwa sikap dan perilaku masyarakat dan penyelenggaraan Negara seringkali 
membentuk kebiasaan, tradisi, dan bahkan kebudayaan secara faktual dan potensial dapat menumbuhkan sikap permisif terhadap tindakan yang bersifat nepolitistik, kolutif, dan koruptif.

Onghokham dalam Mochtar Lubis dan James C. Scot (1985:115-116) mengatakan bahwa korupsi adalah satu gejala sosial dan politik dalam sejarah dan masa kini. Dalam tulisan tersebut Onghokham mengungkapkan tentang sumber-sumber tradisional dari gejala korupsi di Indonesia yang bermula dari ketika adanya pemisahan antara kepentingan pribadi dengan kepentingan publik. Pada masa kerajaan, korupsi memang tidak dikenal, karena saat itu belum ada pemisahan secara jelas antara kepemilikan private dengan kepemilikan publik. Raja sebagai pemimpin tradisional kerajaan menganggap bahwa keseluruhan sumberdaya dalam wilayahnya adalah milik raja sebagai pribadi. Semua penghasilan kerajaan menjadi bagian dari kepemilikan pribadi.

Menurut Ongkhokham (1985) selanjutnya, korupsi baru dikenal ketika sistem pemerintahan modern mulai dikenal, justru ketika kolonialisme Belanda mulai memisahkan antara kepentingan pribadi dengan kepentingan umum. Dalam sistem tersebut, sudah mulai dikenal istilah pejabat sebagai orang yang diberi wewenang (otoritas/kekuasaan), karena dipercaya umum, dan penyalahgunaan darinya adalah pengkhianatan terhadap kepercayaan umum yang diberikan kepadanya. Korupsi kemudian menjadi istilah yang menyertainya. Korupsi muncul dari penyalahgunaan kewenangan (abuse power) yang berakibat pada kerugian kepentingan umum atau negara. Korupsi dalam konteks ini berupa penyelewengan kepentingan umum demi kepentingan pribadi yang dapat berupa penyelewengan keuangan negara, pemerasan atau pungutan liar, suap, hingga menarik keuntungan dari kewenangan.

Pengaruh kehidupan feodalistik-patrimonial yang melembaga cukup lama dalam kenyataannya tidak bisa hilang dalam masyarakat Indonesia. Tata kelola kewenangan kekuasaan dengan prinsip kerja modern pun tak mampu menggeser sifat patrimonial di dalamnya. Wajah modernitas birokrasi dengan langgam tradisional begitu kukuh dalam pengelolaan kewenangan. Tidak heran jika mengapa isu Korupsi, Kolusi dan Nepotisme (KKN) adalah trending topic yang tidak pernah selesai dan selalu muncul ke permukaan dalam berbagai peristiwa penyelewengan kekuasaan. Sebagai bangsa dengan kultur patrimonial (baca juga: paternalistik) yang kuat, unsur-unsur kekerabatan hampir tidak pernah bisa dilepaskan dalam hampir semua pengelolaan kekuasaan. Yang menarik adalah bahwa sistem kekerabatan di Indonesia tidaklah bersifat tunggal, melainkan ia bisa saja melibatkan keluarga 'batih' atau keluarga besar yang tidak melulu berarti ayah-ibu dan anak. Prinsip "keluarga batih" itu mengartikan bahwa hubungan kekerabatan itu bisa dirunut secara geneologis dalam konsep 'trah' (dalam tradisi Jawa), yakni sebuah hubungan darah meskipun tidak harus sekandung.

Dalam prinsip kekerabatan yang demikian maka logika birokrasi modern pun seringkali tidak kuasa mengubah watak birokrat untuk mengarusutamakan kepentingan keluarga daripada kepentingan publik. Watak birokrasi yang patrimonial memiliki kecenderungan menyalahgunakan kewenangan demi keuntungan pribadi maupun kekerabatannya. Hal ini bisa ditandai dengan berbagai kasus KKN yang melanda birokrasi kita sejak jaman dulu hingga sekarang. Dalam konteks kekinian, watak birokrasi yang masih bersifat tradisional meskipun sistem yang digunakan sudah modern masih saja ditemukan.

Kompas (5 Desember 2012) melansir temuan institusi maupun perorangan yang mengkorupsi uang negara sepanjang 2004 sampai 2012. 
Tabel 1.

Keterlibatan institusi dalam korupsi 2004-2013 (Kompas, 5/12/2012)

\begin{tabular}{cc}
\hline Institusi/Perorang & Jumlah \\
\hline Eselon I, II, III & 106 \\
Swasta & 69 \\
Anggota Dewan & 65 \\
Bupati/Walikota & 31 \\
Gubernur & 8 \\
Komisioner & 7 \\
Kementrian & 6 \\
Hakim & 5 \\
Duta Besar & 4 \\
Jaksa & 2 \\
Lain-Lain & 31 \\
\hline
\end{tabular}

Temuan ini memberikan suatu isyarat bahwa unsur birokrat masih menduduki peringkat pertama dalam kasus korupsi. Birokrat dianggap sebagai orang yang memiliki kewenangan mengelola kekuasaan. Kewenangan pengelolaan kekuasaan sesungguhnya sudah diatur sedemikian rupa melalui berbagai aturan tata kelola pemerintahan, yang seharusnya tidak memungkinkan terjadinya penyalahgunaan kekuasaan (abuse of power). Namun demikian, mengapa kasus korupsi tetap saja melibatkan unsur-unsur birokrasi? Realitas ini tentu saja menarik untuk ditelusuri dan diungkapkan secara komprehensif.

Dalam sistem budaya patrimonial dengan sifat kekerabatan kental yang membangun suatu budaya patron (atasan-majikan) dan client (bawahan-pesuruh). Dalam konsepsi yang demikian, elit birokrat akan berposisi sebagai patron dan karyawan di bawahnya adalah clien. Bahkan dalam sistem kekerabatan yang kental, seorang elit birokrasi yang dapat membawa serta keluarga batihnya dalam gerbong briokrasinya akan berposisi sebagai patron (atasan) dan lainnya adalah bawahan. Mekanisme kerja pun tidak ubahnya seperti majikan dan buruh. Patron-client melahirkan mekanisme kerja 'balas budi', karena patron sudah dianggap sebagai atasan yang pernah memberikan budi baik kepada bawahan.

Tingginya tingkat korupsi yang dilakukan oleh birokrasi membuat negara ini seringkali disebut sebagai negara kleptokrasi. Kleptokrasi berhubungan dengan suatu istilah yang digunakan untuk menunjukkan begitu seriusnya tingkat korupsi suatu negara. Gejala kleptokrasi biasanya ditandai dengan keinginan kuat pengelola negara memperoleh keuntungan melalui korupsi sebagai tujuan organisasi, kepentingan negara dan kepentingan penguasa menjadi kabur batasnya. Kleptokrasi merupakan suatu bentuk korupsi tingkat tinggi (heavy corruption). Istilah ini berasal dari istilah penyakit kleptomania yang berarti kebiasaan mencuri dari seseorang yang tidak dilakukan untuk pencaharian. Suatu istilah terkait dengan penyakit psikologis seseorang untuk memiliki barang melalui pencurian. Menurut Muhammad Mustofa (2010:vii) ketika korupsi di Indonesia begitu serius, apalagi jika dilakukan oleh birokrasi, maka dapat dikatakan bahwa kleptokrasi merupakan ciri korupsi di Indonesia. Dengan ciri kleptokrasi, maka tindakan korupsi menjadi budaya atau dipandang secara lumrah saja oleh sebagian orang. Oleh karenanya, menjadi wajar jika korupsi kemudian sulit diberantas atau dicegah.

Ciri suatu negara kleptokrasi seolah lekat dalam kondisi pengelolaan kenegaraan kita, yakni dengan tingginya korupsi di kalangan birokrasi. Ciri lainnya adalah terjadinya persekongkolan antara penguasa dengan pengusaha dalam tindakan korupsi. Persekongkolan birokrat dengan korporat tersebut terutama dalam rangka memperoleh keuntungan dengan cara-cara yang merugikan negara. Negara dalam tipologi demikian umumnya lebih mengandalkan pembiayaan negara pada sumber daya alam yang dieksploitasi secara tidak terkendali, yang orientasinya lebih memakmurkan birokrat yang korup dan korporasi mitranya daripada kemakmuran rakyatnya (Muhammad Mustofa 2010: viii). 
Persekongkolan penguasa dengan pengusaha memang memberikan peluang bagi selalu terjadinya perilaku koruptif. Persekongkolan ini jelas merupakan kerjasama 'jahat' karena merugikan keuangan negara. Hubungan antara birokrat dengan korporat lazimnya disebut sebagai 'perselingkuhan', yakni sebuah hubungan tidak normal dari dua hal yang tidak sama. Karena logika korporat adalah logika keuntungan, sedangkan logika birokrat adalah logika kepentingan pengabdian pada publik. Ketika birokrasi dan korporat menjalin hubungan tidak normal, maka logika pengabdian pada pelayanan publik seringkali terkalahkan dari orientasi mendapatkan keuntungan pribadi.

Perspektif inilah yang kemudian menguatkan suatu tesis bahwa penguasa (birokrat) dengan pengusaha (korporat) haruslah dua kekuatan yang harus dipisahkan. Bersatunya dua kekuatan tersebut menjadikan negara mudah dikendalikan oleh kekuatan birokratik dengan langgam korporasi yang bukan untuk menguntungkan negara, melainkan menguntungkan formasi kekuasaan politiknya. Teori klasik dari kalangan Marxis (Suseno 1996) menunjukkan suatu kecenderungan kuat perilaku koruptif mudah terjadi bagi penguasa yang dikuasai oleh pengusaha, apalagi ketika penguasa sekaligus dengan sendirinya adalah pengusaha. Naluri dasar manusia biasanya mudah tergoda dengan simbol-simbol material, termasuk di dalamnya adalah naluri penguasa. Itulah sebabnya, mengapa kekuasaan dalam berbagai bentuk pemerintahan, selalu dibatasi agar tidak menjadi absolut dan tidak terkendali.

Itulah sebabnya, sifat birokrasi yang paternalistik telah memberikan peluang terjadinya politik patronclient yang mendorong terjadinya tindakan korupsi secara sistemik, melibatkan banyak orang. Seorang pejabat menjadi patron bagi setiap orang yang ada dibawah koordinasinya, yang lain adalah client yang harus menuruti kemauan dari patron. Korupsi menjadi sistemik karena melibatkan setiap unsur dalam bidang-bidangnya. Beberapa kasus korupsi yang banyak ditangani menunjukkan modus operandi adanya ketidakmampuan bawahan (staf) menolak perintah atasan (elit birokrasi) dalam memanipulasi data atau laporan pertanggungjawaban kegiatan atau staf dan atasan bekerjasama membuat laporan kegiatan fiktif agar mendapatkan keuntungan dari pengelolaan kewenangan. Menjadi wajar jika tender proyek selalu dimenangkan oleh perusahaan-perusahaan yang memiliki kedekatan dengan birokrasi.

\section{Fenomenologi korupsi dalam persepsi publik dan moralitas kekuasaan}

Sub bab ini mencoba mengungkapkan persepsi publik terkait dengan persoalan korupsi yang banyak terjadi di Indonesia. Persepsi publik ditemukan melalui wawancara mendalam dan focus group discussion (FGD) dengan pendekatan fenomenologi, yakni meletakkan segala sesuatu dari sudut pandang subjek yang diteliti. Bagaimanapun, persepsi publik terhadap kasus korupsi seringkali berpengaruh terhadap partisipasi mereka dalam isu-isu korupsi di Indonesia.. Perspektif yang salah terkait dengan kekuasaan, seringkali mendorong subjek kuasa mudah melakukan praktik korupsi, baik yang disadari maupun tidak. Fenomenologi korupsi ini berupaya untuk menjelaskan betapa hasrat atau naluri kuasa dari subjek kuasa begitu kuat sehingga cenderung menempatkan kekuasaan sebagai segalanya. Kekuasaan sebagai amanah, berubah bentuknya menjadi berkah. Sehingga, setiap kekuasaan selalu dianggap sebagai berkah yang dapat menghasilkan berbagai fasilitas bagi hidup dan kehidupannya. Menjadi wajar ketika praktik korupsi dalam kenyataannya selalu melibatkan kekuasaan. Hampir tidak pernah ada korupsi terjadi di luar struktur kekuasaan. Itulah sebabnya, dalam sub bab ini, penelitian ini mencoba mengungkapkan betapa relasi kekuasaan dan moralitas menjadi isu penting untuk dijelaskan dan dicari hubungan logis antara keduanya.

Menguatnya birokrasi dan partai politik sebagai pelaku korupsi, seolah mengasumsikan bahwa reformasi birokrasi ternyata tidak berbanding dengan reformasi di bidang pemberantasan korupsi. Seolah selalu saja ada modus baru dari setiap bentuk pemberantasan korupsi di lakukan, Hal ini menguatkan suatu indikasi bahwa watak korupsi di Indonesia mudah dilakukan oleh birokrasi yang masih menunjukkan wajah patrimonialnya. Watak korupsi dalam birokrasi patrimonial yang kemudian didukung oleh perilaku elite politik mendukung kian masifnya praktik korupsi yang melibatkan oknum birokrasi dan oknum partai politik. 
Korupsi kemudian menjadi sebuah fenomena yang sifatnya massal, yang dalam perspektif Bourdieu disebut sebagai banalitas korupsi. Dimana korupsi tidak lakukan oleh sendiri, termasuk juga tidak dinikmati sendiri. Korupsi selalu melibatkan suatu lingkaran struktural di dalamnya. Banalitas korupsi tersebut akhirnya memberikan suatu kesan bahwa korupsi dapat diletakkan dalam konteks kebudayaan, yakni terkait dengan persoalan mentalitas serta persepsi yang salah terkait dengan pengelolaan kekuasaan. Kekuasaan dalam konteks ini tidaklah berarti kekuasaan politik semata, melainkan berbagai hal terkait dengan kekuasaan kewenangan.

Fenomenologi korupsi menempatkan korupsi sebagai objek empiris. Kembali kepada objek korupsi secara langsung merupakan bagian tidak terpisahkan dari bagaimana kita mempersepsikan korupsi dalam masyarakat maupun dalam birokrasi. Salah satu tujian penulisan ini mengungkapkan bagaimana persepsi masyarakat terhadap perilaku korupsi, maka fenomenologi menjadi pendekatan penting untuk dilakukan. Masyarakat menjadi objek yang dianggap memiliki pengalaman yang secara langsung berhadapan dengan fakta korupsi yang melibatkan kekuasaan.

Realitas empirik yang terjadi adalah adanya fakta betapa masyarakat cenderung tidak memiliki perhatian penuh terhadap perilaku seorang pejabat dari unsur birokrasi yang hidup di lingkungan sekitarnya. Kalau toh ada perhatian, masyarakat lebih menempatkan gaya hidup elit birokrasi tersebut sebagai hak private yang tidak boleh diganggu oleh orang lain. Masyarakat cenderung tidak peduli, meskipun orang tersebut merupakan pejabat publik yang perilaku hidupnya juga perlu diawasi oleh publik. Bagi masyarakat tersebut, jikalau perilaku hidup yang berlebihan itu dilakukan dianggap sebagai kewajaran, karena orang tersebut merupakan pejabat yang mestinya mendapatkan fasilitas dari jabatannya.

Persepsi ini tentu saja menarik. Bisa jadi ini bukan fakta yang bersifat lokal, melainkan umum berlaku dalam sistem sosial kita yang memang menganut prinsip sikap hormat dan prinsin rukun (Suseno 1999:39-60). Menggunakan anggapan Hildred Geertz, Magnis Suseno menyebut adanya dua kaidah paling menentukan dalam pola pergaulan masyarakat kita, terutama yang hidup di Jawa, yakni (1) dalam setiap situasi manusia hendaknya bersikap sedemikian rupa hingga tidak sampai menimbulkan konflik, dan (2) menuntut agar manusia dalam cara bicara dan membawa diri selalu menunjukkan sikap hormat terhadap orang lain, sesuai dengan derajat dan kedudukannya. Kaidah pertama disebut sebagai kerukunan, dan kedua disebut sebagai sikap hormat. Setiap bentuk interaksi pergaulan masyarakat Jawa setidaknya menggunakan kedua prinsip tersebut sebagai kerangka normatif dalam menentukan tindakan.

Masyarakat dengan sistem sosial yang demikian menghendaki suatu keadaan yang harmonis dalam masyarakat. Keadaan ini mengharuskannya meniadakan berbagai bentuk ketegangan dalam masyarakat atau antar pribadi sehingga hubungan sosial tetap kelihatan selaras dan baik-baik. Masyarakat biasanya menjadi tuntutan kerukunan sebagai yang selayaknya dipatuhi melalui pencegahan segala hal yang mengganggu kerukunan dan keselarasan. Dalam konteks demikian, setidaknya terdapat dua segi tuntutan kerukunan. Pertama, masalahnya bukan pada penciptaan keadaan keselarasan sosial, melainkan lebih untuk tidak mengganggu keselarasan yang diandaikan sudah ada. Prinsip ini bersifat negatif, karena hanya menuntut pencegahan segala kelakuan yang mengganggu keselarasan dan ketenangan. Kedua, prinsip kerukunan pertama-tama tidak menyangkut sikap batin atau keadaan jiwa, melainkan penjagaan keselarasan dalam pergaulan. Yang diatur adalah permukaan hubungan-hubungan sosial yang kentara, yang dicegah adalah konflik-konflik yang terbuka. Itulah sebabnya, mengapa masyarakat kita selalu menuntut agar setiap individu bersedia menomorduakan atau melepaskan kepentingan-kepentingan pribadi, agar tidak terjadi benturan kepentingan satu sama lain (Suseno 1999: 39-40).

Prinsip meniadakan konflik ini membuat masyarakat kita memiliki sikap untuk memperkatakan halhal yang tidak enak secara tidak langsung. Masyarakat mampu menutupi kekecewaannya melalui kebiasaan berpura-pura (ethok-ethok). Kemampuan ini dianggap sebagai keutamaan hidup, sebagai seni yang tinggi dan bernilai positif. Terhadap yang tidak disukainya, masyarakat akan 
menyampaikan melalui sikap tidak langsung atau menyembunyikan perasaan kekecewaan tersebut, kecuali pada keluarga inti.

Konstruksi sistem nilai ini tentu saja berimplikasi kepada sikap dan persepsi masyarakat terhadap gaya hidup pejabat dalam lingkungan sekitarnya. Keinginan untuk hidup harmonis cenderung membuat masyarakat tidak terbiasa kritis terhadap gaya hidup pejabat publik, yang semestinya diawasi oleh sistem dan oleh publik. Inilah yang kemudian membuat kultur pembiaran (ommision culture) terhadap penyimpangan kekuasaan oleh masyarakat. Yang biasa dilakukan biasanya adalah pejabat tersebut hanya menjadi 'perbincangan' rutin dalam obrolan di pos ronda atau warung kopi, tanpa ada penyelesaian yang pasti. Masyarakat sudah terlanjur menerima prinsip rukun sebagai bagian dari tatanan sosial yang harus dijaga. Agar kerukunan dalam masyarakat terjaga, maka seseorang tidak boleh membuat suatu aktivitas yang mengganggu tertib sosial yang sudah ada. Karenanya, menjadi wajar jika masyarakat hampir jarang menjadi whistle blower bagi terjadinya kasus korupsi, minimal dari sikap kritis atas perilaku pejabat di lingkunagn sekitarnya. Padahal jika masyarakat peduli terhadap kasus korupsi, ia akan menjadi komponen penting dalam pemberantasan kasus korupsi. Mengapa demikian, karena dalam lingkungan masyarakat (minimal RT/RW), setiap orang bisa memantau perilaku orang lain secara langsung. Sayangnya, kondisi demikian belum diharapkan bisa muncul pada masyarakat yang masih belum bisa memisahkan antara seseorang sebagai individu masyarakat dengan seseorang sebagai pejabat publik yang bertanggungjawan kepada masyarakat dalam pengelolaan kekuasaannya.

Sikap tidak kritis ini bisa dimengerti sebagai akibat dari ketidakmampuan memisahkan satu individu dengan jabatan yang melekatnya. Terlebih pada masyarakat yang masih bersifat tradisional, meskipun sistem sosialnya sudah menjadi modern. Pada kondisi masyarakat ini, seorang pejabat tetap dianggap sebagai tokoh masyarakat yang harus dihormati dan disegani. Mirip dengan sistem feodalistik yang menempatkan pejabat sebagai priyayi dari lingkungan keraton (ndalem) yang harus dijunjung tinggi martabat sosialnya dan harus tercukupi fasilitas hidupnya. Makanya, bagi mereka menjadi aneh rasanya jika seorang pejabat dalam sebuah lingkungan birokrasi tidak memiliki fasilitas yang menunjang kehidupannya dan keluarganya, seperti rumah mewah, mobil, dan harta benda lainnya.

Dalam kultur yang demikian, maka sikap hormat terhadap pejabat publik dalam lingkungan sosialnya menjadi suatu keharusan. Sikap hormat tersebut ditandai dengan menempatkannya sebagai tokoh masyarakat, biasanya menjadi ketua RT/RW. Hilangnya sikap kritis terhadap pejabat tersebut merupakan konsekuensi logis dari sikap hormat tersebut, termasuk ketika pejabat publik tersebut memiliki harta kekayaan yang melebih profilnya. Itulah sebabnya, ketika pejabat tersebut ternyata menjadi tersangka kasus korupsi, mereka baru menunjukkan secara verbal 'rasan-rasan' yang dulu dibatinnya.

Terlepas dari konstruksi sistem sosial tersebut, tampaknya yang sedang terjadi dalam masyarakat kita adalah sikap dan persepsi yang keliru terhadap sebuah jabatan sekaligus persepsi terhadap korupsi. Jabatan dalam birokrasi pemerintahan dan kasus korupsi seolah merupakan kepentingan politik kenegaraan, dan bukan persoalan masyarakat. Mereka tidak menyadari bahwa jabatan seseorang dalam birokrasi pemerintahan dan kasus korupsi sangat erat dengan persoalan masyarakat. Pejabat publik merupakan abdi negara yang melayani kepentingan publik. Dalam sistem birokrasi modern, pejabat publik sesungguhnya adalah pelayan publik, yang memberikan rasa nyaman bagi fasilitasi kebutuhan masyarakat. Dalam artian ini, maka pejabat publik berhubungan langsung dengan pelayanan kebutuhan masyarakat. Karenanya, jabatan publik tersebut berimplikasi kepada tanggungjawab publik dalam pengelolaan kekuasaannya.

Begitu pula dengan kasus korupsi. Mengapa publik cenderung tidak kritis terhadap pejabat publik yang korup dan terhadap fenomena korupsi yang belakangan masif terjadi. Tidak lain, karena mereka menganggap bahwa korupsi itu uang negara dan bukan harta kekayaan masyarakat. Mereka merasa tidak pernah merasa kehilangan, karena tidak pernah merasa memiliki harta negara yang dikorupsi. Masyarakat yang demikian lebih sibuk dengan persoalan tubuh personal daripada tubuh sosial 
(Fromm 1995:17). Tubuh personal mengindikasikan tentang kesalehan personal, tubuh sosial mengasosiasikan kesalehan sosial. Tubuh personal lebih sibuk merawat dan memelihara kepemilikan sendiri dan tidak peduli dengan milik (tubuh) sosial. Bercermin dari realitas ini, tidak berlebihan jika dalam masyarakat seperti ini, ruang publik tidak pernah aman dari perilaku anarkis daripada kepedulian terhadap ruang personal. Setiap ruang publik kita, seperti telepon umum, WC umum, fasilitas umum dan sebagainya selalu tidak terawat dan rusak sebelum waktunya.

Dalam konteks inilah maka kondisi kultural masyarakat kita memang masih perlu diarahkan untuk memiliki kepedulian terhadap tubuh sosial. Tubuh sosial ini terkait dengan kepemilikan publik atau negara. Karena dalam alam pikiran yang demikian, pencuri ayam yang mencuri harta milik personal, dianggap sebagai perilaku buruk daripada koruptur yang mencuri harta publik atau negara. Implikasi logisnya, perlakuan terhadap pencuri ayam seringkali lebih buruk daripada koruptor. Sanksi sosial yang diberikan oleh masyarakat pun terkadang tidak adil antara pencuri ayam dengan koruptor.

Realitas ini menjadi kendala kultural dalam setiap pemberantasan korupsi. Ketidakpedulian masyarakat terhadap tubuh sosial akhirnya membuat pelaku korupsi merasa tidak pernah terawasi dalam lingkungan sosialnya. Mengapa masyarakat harus memiliki sikap kritis kepada pejabat publik, karena dalam jabatannya bersembunyi amanat publik yang harus dipertanggungjawabkan. Mendorong masyarakat untuk memiliki kesadaran publik ini memang membutuhkan suatu upaya terus menerus yang dilakukan oleh berbagai pihak. Perlu strategi kebudayaan agar masyarakat berpartisipasi terhadap upaya pemberantasa korupsi. Kalau hanya mengandalkan pada kekuatan aparat hukum, maka seringkali tidak efektif karena, pertama terkait dengan keterbatasan sumberdaya, kedua terkait dengan alat bukti yang membutuhkan waktu lama untuk menunjukkan pembuktiannya. Melalui peran serta masyarakat, maka setiap pejabat publik (yang pasti hidup dalam lingkungan masyarakat) hidupnya selalu terawasi, tidak saja oleh sistem, melainkan juga oleh masyarakat.

Ketidakpedulian publik terhadap kasus korupsi menunjukkan ketidakberdayaan masyarakat terhadap penyalahgunaan kekuasaan, apalagi ketika dalam korupsi terdapat mekanisme 'silih', yakni suatu mekanisme korupsi yang hasl-hasilnya tidak dinikmati sendiri, tetapi dibagikan kepada publik dalam bentuk bantuan sosial, sodaqoh, dan sebagainya. Pada saat itu, masyarakat akan melihatnya sebagai sosok yang 'berhati mulia' dan dermawan. Mekanisme silih ini mampu mengelabui publik, yang semestinya merupakan korban, tetapi menjadi bagian yang seolah diuntungkan dengan adanya bantuan kepada mereka.

Mengacu pada pemahaman di atas, jelas menunjukkan bahwa ketiadaan perasaan bersalah (quilt culture) para pelaku korupsi, apalagi ketika publik membiarkannya serta menerima hasil-hasil korupsinya. Situasi ini akhirnya hanya mampu menyingkap struktur-struktur kejahatan korupsi dan mentalitas masyarakat yang membentuknya. Korupsi di Indonesia, karena diparktikkan oleh banyak orang dan dalam berbagai tingkat lalu sifatnya sudah menjadi struktural. Tidak heran, jika koruptorkoruptor yang tertangkap adalah orang yang pada masa lalu berteriak hancurkan KKN, berantas korupsi, dan sebagainya. Mereka seolah tidak dapat melepaskan diri dalam jaring kekuasaan yang mendorong penguasan melakukan korupsi (Haryatmoko 2003: 131).

\section{Simpulan}

Optimalisasi pemberantasan korupsi dalam banyak hal sangat tergantung dari sejauh mana konsistensi penegakan hukum terhadap pelaku korupsi, komitmen menegakkan hukum serta disiplin para penegak hukum. Namun demikian, dalam menegakkan ketiganya seringkali ditemukan berbagai kendala kultural yang menjadikan pemberantasan korupsi tidak optimal.

Salah satu penyebab masifnya korupsi di Indonesia adalah kultur patrimonial dalam birokrasi kita. Struktur birokrasi di Indonesia sudah berubah menjadi birokasi yang rasional modern, sebagaimana dilembagakan oleh Max'Weber, tetapi karena kultur patrimonial masih cukup kuat, menjadikan 
birokrasi justru hanya menjadi peluang bagi terjadinya prakti korupsi dan nepotisme. Kultur patrimonial atau paternalistik dalam bahasa yang berbeda cenderung menempatkan kekuasaan sebagai sarana menguntungkan kepentingan sendiri dan keluarga. Dalam sistem birokrasi yang berwatak paternalistik tersebut memiliki kecenderungan untuk menjadikan sistem kekerabatan sebagai bagian yang harus menerima keuntungan dari kekuasaan yang dimilikinya.

Dalam konstruksi sosial, korupsi lebih dianggap sebagai kejahatan terhadap negara, bukan kejahatan terhadap masyarakat. Hal ini ditandai dengan ketidakpedulian masyarakat terhadap berbagai tindak pidana korupsi. Rendahnya partipasi masyarakat terhadap tindak pidana korupsi, selain disebabkan ketidakpahaman mereka terhadap korupsi dan ruang lingkupnya, juga karena persepsi yang salah terkait dengan persepsi ruang publik dan ruang personal. Ketidakpahaman ini membuat mereka juga seringkali tidak dapat memisahkan seeorang sebagai anggota dalam masyarakat, sekaligus juga seseorang yang memiliki jabatan publik.

Kepedulian yang diharapkan muncul lebih terkait dengan kepemilikan harta benda sendiri, bukan kepada harta kekayaan negara. Itulah sebabnya, mereka seringkali tidak merasa kehilangan ketika uang negara dikorupsi. Masyarakat juga cenderung tidak menganggap diri sebagai korban, ketika uang negara dikorupsi. Kondisi ini menempatkan perilaku koruptif selalu mendapatkan pembiaran dalam masyarakat kita. Tragisnya, jika seorang koruptor mampu merepresentasikan diri sebagai orang dermawan di mata publik. Praksis, keseluruhan hasil-hasil kejahatannya akan dapat ditutup dari kemampuannya menunjukkan diri sebagai orang 'dermawan; di mata publik.

\section{Daftar Pustaka}

Bakker JWM (1984) Filsafat Kebudayaan. Yogyakarta: Kanisius Foucault M (1975) Discipline and Punish: The Birth of Prison. London: Penguin.

Fromm E (1995) Masyarakat yang Sehat. terjemahan Thomas bambang Murtianto, Jakarta: Yayasan Obor

Harrison LE and Hutingtong SP (2000) Membangun Budaya Bangsa Jakarta: Yayasan Obor.

Hartiningsih M (ed) ( 2011) Korupsi yang Memiskinkan. Jakarta: Kompas

Haryatmoko (2003) Etika Politik dan Kekuasaan. Jakarta: Kompas

Haryatmoko (2010) Dominasi Penuh Muslihat, Akar Kekerasan dan Diskriminasi. Jakarta: Gramedia

Lubis M (2001) Manusia Indonesia. Jakarta: Buku Obor.

Lubis M dan James CS (Eds) (1985) Bunga Rampai Korupsi. Jakarta: LP3ES.

Mustofa M (2010) Kleptokrasi: Persekongkolan Birokrat-Korporat sebagai Pola White-Collar Crime di Indonesia. Jakarta : Kencana Prenada Media.

Suseno FM (1999) Etika Jawa, Sebuah Analisa Falsafi tentang Kebijaksanaan Hidup. Cet. 9. Jakarta: Gramedia Utama. 